\title{
Foreign Language Teachers' Roles and Training in Inter-cultural Education under the New Situation
}

\author{
Guan Jian \\ School of Foreign Languages,Jilin Agricultural University, Changchun, Jilin 130118
}

\begin{abstract}
Under the new situation, how to face the communication barriers and possible conflicts brought from the different cultures is a problem which needs to be solved in the intercultural communication. Meanwhile, it also brings new challenges to the foreign language teachers, the main participants of the foreign language curriculum and the training. Here, the reposition of foreign language teachers' roles and their training is especially important.
\end{abstract}

Keywords- intercultural education; foreign language teachers; reposition of roles; teacher's training

\section{INTRODUCTION}

For globalization, acting on international convention, China's access to WTO and Beijing Olympic Games, foreign language has close relationship with Chinese. The language courses of schools and foreign language training market of the society is vigorous. But it is easy for people to neglect cultural learning which has close relationship with foreign language. We know that language has close relationship with culture, which makes cultural introduction important in foreign language teaching. Under the situation, there is no doubt that the foreign language teachers face new challenge. For foreign language teaching, how to cultivate foreign language talents under new situations is a new topic with important historical significance, especially it is a great challenge for foreign language teachers.

\section{REDEFINITION OF LANGUAGE TEACHING AND LEARNING AND EXISTING PROBLEMS OF CROSS-CULTURAL EDUCATION}

For the relationship between language and culture, the researches at home and abroad consider that in language teaching and learning, language is the carrier of culture, and culture is rooted in language. It is an international high-tech era, information era and economic globalization era. The economic and cultural exchanges between countries increase, and there are more and more contact and conflicts between different cultures. Cross-cultural communication can't achieve the expected objective. It not only depends on the language level of communication parties, but also depends on the degree of understanding cultural knowledge of both parties, which indicates the important significance of cultural factors in language teaching. Wang Zuoliang considers if we don't understand social culture in language, there is no people really mastering language. Therefore, language teaching and learning has close relationship with cultural introduction and learning.
Cross-cultural education under the new situation requires that foreign language teachers need to develop their majors and personal competence from multi-level perspectives. The teachers need to change personal belief, professional knowledge, attitude and skills (Sercu, 1998:256), and need to have basic insight on human culture, cultural learning theory and cross-cultural communication (Sercu, 2002b:152 ) . In addition, Field pointed out that foreign language teachers need to anticipate and understand the requirements of students and provide professional help.

The redefinition of language teaching and learning makes many educational institutions change education standard and strategy. It is repeatedly strengthened to cultivate crosscultural communication ability of students. However, in practice, cross-cultural education still falls behind language teaching. Effective cross-cultural education is very difficult. Firstly, in some regions, the people don't admit that cultural teaching has problems. There are many teachers still using traditional teaching mode and teaching means now, which inhibits the initiative and activity of students participating in communicative activities, which affects the improve of cross-cultural communication ability of students. There are some teachers only making themselves the initiators of language knowledge, and the students are containers of language knowledge, which can't plays the role of cognitive subject of students (Zhang Yan, 2006). Secondly, cultural teaching has no effective method, which makes teachers difficult to establish teaching objective. In many cases, the established cultural objectives have no relationship with language teaching and learning. Thirdly, cultural teaching objective has been established, but it is difficult to define to introduce what kind of cultural factors to enhance cross-cultural communication ability of students. Lastly, there are researches indicating that most teachers have no a systematic plan for how to improve teaching cross-cultural communication ability or how to change traditional foreign language teaching (Sercu, 2002b: 162). And there is no clear standard improving status (MET, 1993). They still use traditional teaching methods, and don't use new communication methods and task-based teaching theory to guide teaching. The above problems can be attributed to the fact that the teachers are not ready and they are busy in completing various objectives which can't be achieved. 


\section{NEW REQUIREMENT ON FOREIGN LANGUAGE TEACHERS — REPOSITIONING ROLES}

Foreign language teachers need to burden various responsibilities such as educating students and teaching skills, which makes many foreign language teachers lost. The objective of them is to make students understand the world, and makes students communicate across the boundary of language and culture, which plays active role in the world

(Kelly, 2002: 3 ) . The cultural workers play the role of helping and challenging the interaction of students with other culture (Jones, 2000: 169). The role makes them have responsibility to change consciousness of students.

As the receiver and disseminator of different cultures, foreign language teachers not only need to be subject to the national culture, but also must step into the culture in other countries. The class is the product of the combination of two cultures which is the cross-cultural place of communication of foreign learning materials and language form with native learners. Foreign language teachers play the role of disseminator and coordinator between foreign language information and native learners. Cross-culture is the evident characteristic of foreign teachers. It is urgent to reposition the role of foreign language teachers.

(1) The role of foreign teachers should be positioned as the multicultural reader, and is the guider of cultivating cross-cultural communication ability. Foreign language teachers should understand and identify multi culture, and should establish multi-cultural consciousness and crosscultural consciousness. Foreign language teachers should realize the difference between different cultures. Foreign language teachers should become the communication bridge between personal culture of students and British and American culture, and should be the guider of cultural communication and cross-cultural communication ability cultivation.

(2)The foreign language teachers should be positioned as care giver of students. The care is from all students with different backgrounds, which creates and establishes educational background expressing social fairness for students. The teaching of teachers should include the studies, emotion and social requirements of students. The foreign language teachers under new situation should believe that each student has intrinsic learning requirements and need to cultivate achievement motivation of students with different backgrounds.

(3) The foreign language teachers should be positioned as the expert of native knowledge culture. Cross-cultural education not only needs to cultivate cross-cultural consciousness of students, but also needs to focus on cultivating native consciousness. Foreign language teachers not only need to realize the value of native knowledge culture and native cognitive style, but also should realize the important significance of them for physical and mental development of students and continuous development of native society. The teachers should feel the existence of native knowledge culture, protect and develop the value of native knowledge culture and know how to excavate and research the knowledge culture of schools.

(4) The foreign language teachers should be repositioned as action researcher, and the research of teaching theory and method. Foreign language teachers should fully consider multi-cultural background, the sub-culture and community culture of students. Cultural difference is easy to make contradictions between teaching methods of teachers and learning methods of students. Therefore, foreign language teachers should career development consciousness of selfdevelopment and life-long learning, and reflect the teaching methods. And the teachers should make researches in teaching process and develop new teaching practice or improve courses. Under new situation, it is difficult for foreign language teachers to depend on the existing theory and experience to solve the new problems of teaching concept and teaching methods. It requires the teachers to reflect, observe and analyze the problems to find out the solutions.

\section{Suggestions FOR TEACHERS' TRAINING OF CROSS- CULTURAL EDUCATION}

Liu Runqing ( 1999 ) proposed that foreign language teachers not only need to know what to teach, but also need to know how to teach. Language is a tool and a carrier. The connation of language is knowledge and culture, and language can't be separate from knowledge and culture. But the status is that many foreign language teachers don't know how to introduce cultural content in the process of cultivating cross-cultural communication ability. Therefore, teachers' training of cross-cultural education is especially important.

There are two forms for the training of foreign language teachers. One form is degree education before job. The colleges open various foreign language courses teaching language, culture and teaching theory. The method aims at the students who prepare for joining specialized teachers but have no teaching experience. The other form is on-the-job teacher train. The teachers have teaching experience, but may have no systematic learning or lack of the latest teaching theory. However, unfortunately, the teachers' training of two forms is independent.

The most important problem of teachers' training is the connection between theoretical framework of concept and education and practice. Many teachers accept some concrete training in the professional career, and lack of chances understanding the updating teaching practice. For teachers' training of cross-cultural education, there are relevant researches in Europe and America. The research report in America indicates that teachers' training lack of moral culture (Sockett and LePage, 2002). In Europe, the experts advocate the teaching method of adding wide cross-culture and social culture in teachers' training. In fact, the training can't help the teachers to process cross-cultural problems. Cross-cultural education lacks of systematic methods, which means that the teachers have no deep understanding on the cultural nature and connotation of teaching subject. 
Therefore, teachers' training of cross-cultural education needs systematic education theory and modern education ways and methods.

Therefore, the paper proposes multi-channels to establish teaching staff, and improve the comprehensive quality and ability of foreign language teachers. For example, the teaching competent department actively creates conditions for teachers to provide opportunities of language and culture communication, enhances the communication with other educational institutions and develops cross-cultural education researches. The paper also proposes that the teachers can be selected for professional development in the target language country. And the foreign language experts can be employed to develop short-term training for foreign language teachers. The teachers should be encouraged to participate in seminars at home and abroad, which not only can improve the theoretical quality of teachers and change the knowledge structure, attitude and teaching sill of teachers, but also can promote comprehensive and sustainable development of foreign language teachers, and realize teaching objective of cultivating cross-cultural communication ability, which meets the requirements of society cultivating cultural talent in the new century.

\section{CONCLUSIONS}

Improving cross-cultural communicative competence not only needs educational policy, learning materials or study abroad, but also depends on the understanding and teaching of teachers on cross-cultural communication. And crosscultural communication ability of teachers should be improved by proper training.
Kohonen proposed that professional development is a problem of time, effort, dedication and support (2002:49). The teachers master the time, effort and dedication. However, the teachers need a powerful external coordination. Only common effort of relevant departments and educational institutions can make the teachers have confidence to fulfill their responsibilities.

\section{REFERENCE:}

[1] Luo Changpei, Language and culture [M], Beijing: Language Publishing House, 1989.

[2] Zhao Yang, Introduction of cultural factors in foreign language teaching from the perspective of culture [J], Foreign Language, 2009(5): 121123.

[3] Zhang Yan, Change of teaching theory of foreign language and role conversion of foreign language teachers [J], Sino-US English Teaching, 2006(10):40-43

[4] Liu Runqing, English teaching in universities [M], Foreign Language Teaching and Research Press, 1999.

[5] Sockett, H. and P. LePage (2002). The missing language of the classroom. Teaching and Teacher Education, 18 (2): 159-171

[6]Field, (2000). Issues in modern foreign languages teaching. London: Routledge.

[7] Jones, B. (2000). Developing cultural awareness. Issues in modern foreign languages teaching. Routledge.

[8] Sercu, L. (2002b). Implementing intercultural foreign language education. Language Awareness, 150-165.

[9] Sercu, L. (1998). In-service teacher training and the acquisition of intercultural competence. Approaches through drama and ethnography . 255-289. Cambridge University Press.

[10] Kohonen, V. (2002). From isolation to interdependence in ELT, 40-49. Whitstable: IATELF. 